\title{
Zgrzewanie garbowe w obliczeniach metodą elementów skończonych
}

\section{Projection welding by finite elements method calculation}

\section{Streszczenie}

W artykule przedstawiono wyniki optymalizacji procesu zgrzewania garbowego blach (garb niepełny) dla materiału DX53 i grubości $1,5 \mathrm{~mm}$. Przeprowadzono obliczenia MES z wykorzystaniem oprogramowania SORPAS. Dokonano zmian parametrów zadanych procesu zgrzewania w szerokim zakresie tj. prądu zgrzewania od 8 do $12 \mathrm{kA}$, siły docisku elektrod od 110 do 440 daN (od $50 \%$ do $200 \%$ wartości nominalnej) i czasu zgrzewania 300 ms. Uzyskane wyniki przedstawiono w formie tabelarycznej, obrazów rozkładu temperatury i analizy graficznej wielkości jądra zgrzeiny od parametrów zadanych (prąd zgrzewania, siła docisku elektrod) wykorzystując oprogramowanie do analizy danych STATISTICA.

\section{Abstract}

The article presents the results of the optimisation of projection welding of $1.5 \mathrm{~mm}$ thick DX53 steel grade sheets (incomplete projection) carried out with the help of a pneumatic electrode pressure system. The research-related FEM calculations were made using the SORPAS software. Welding process pre-set parameters were changed in a wide range of a) welding current ( $8 \mathrm{kA}-12 \mathrm{kA})$, electrode pressure force (110daN - 440daN) (from $50 \%$ to $200 \%$ of the nominal value); welding time being $300 \mathrm{~ms}$. The results obtained, depending on the pre-set parameters (welding current, electrode pressure force) are presented in the form of tables as well as the images of temperature distribution and of the weld nugget graphic analysis. The presentation of the results was prepared using the STATISTICA data analysis software.

\section{Wstęp}

Zgrzewanie garbowe ze względu na możliwość równoczesnego uzyskiwania kilku czy kilkunastu zgrzein w jednym cyklu zgrzewania, szczególnie w elementach o złożonych kształtach (nierzadko różniących się właściwościami fizycznymi) znajduje szerokie zastosowanie $w$ obecnych technikach wytwarzania konstrukcji. Poprawny dobór parametrów zgrzewania (prądu i czasu jego przepływu oraz siły docisku) jest szczególnie ważny ze względu na specyfikę odkształcania się

Dr inż. Zygmunt Mikno, mgr inż. Szymon Kowieski - Instytut Spawalnictwa, Gliwice, dr inż. Zbigniew Bartnik, dr inż. Wiesław Derlukiewicz - Politechnika Wrocławska. garbu szczególnie niepełnego (w zgrzewaniu blach) podczas tworzenia połączenia zgrzewanego od którego oczekujemy zadowalających właściwości wytrzymałościowych. Jak wykazuje przeprowadzona analiza MES ukierunkowana na proces tworzenia się zgrzeiny garbowej, bardzo istotna jest siła docisku zgrzewania, która przy niedostatecznej wartości prowadzi do wyprysku ciekłego metalu z jądra tworzonej zgrzeiny, a zbyt duża uniemożliwia uzyskanie wymaganej średnicy jądra zgrzeiny której wskaźniki wytrzymałościowe dalekie są od oczekiwanych. W oparciu o wyniki analiz numerycznych MES oraz weryfikacji eksperymentalnej, wskazana jest korekta wstępnych parametrów zgrzewania (zalecanych przez źródła literaturowe) prowadząca do uzyskiwanie połączeń garbowych o wysokich wskaźnikach wytrzymałościowych. 


\section{Model obliczeniowy MES}

Model obliczeniowy zgrzewania garbowego z wymiarami garbu, siatką elementów skończonych oraz program zgrzewania (parametry technologii) dla blach gatunku DX53 o grubości $1,5 \mathrm{~mm}$ przedstawiono odpowiednio na rysunkach 1 i 2 .

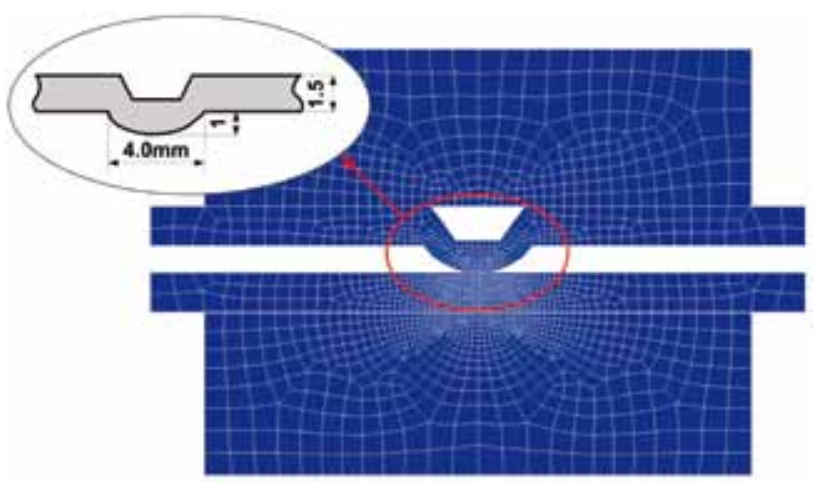

Rys. 1. Model obliczeniowy MES zgrzewania garbowego blach Fig. 1. Projection welding FEM calculation model

Do obliczeń zastosowano oprogramowanie SORPAS [1] w oparciu o model 2D z ok. 1500 stopni swobody. Program Sorpas umożliwiał przeprowadzenie wielu analiz sprzężonych w tym analiz elektrycznych, termiczno-metalurgicznych oraz mechanicznych.

W oparciu o normy i zalecenia przyjęto standardowe parametry zgrzewania i typ garbu [2, 3]:

- natężenie prądu $10 \mathrm{kA}$,

- czas przepływu prądu slop $60 \mathrm{~ms}+240 \mathrm{~ms}$,

- siła docisku elektrod $\mathrm{P}=220 \mathrm{daN}$,

- garb typu C [4].

Dla przyjętych parametrów nominalnych natężenia prądu i siły docisku przeprowadzono szerszą analizę procesu zgrzewania dla zakresu prądów zgrzewania od 8 do $12 \mathrm{kA}(8,9,10,11,12 \mathrm{kA})$ oraz siły docisku elektrod w zakresie od 110 do 440 daN, tj. od $50 \%$ do $200 \%$ wartości nominalnej siły $(110,165,220,330$, 440 daN).

\section{Parametry i wyników obliczeń MES}

W tablicy I zestawiono parametry procesu zgrzewania dla garbu niepełnego typu $\mathrm{C}$, wytłoczonego w blasze (DX53), o grubości zgrzewanych elementów 2 $x 1,5 \mathrm{~mm}$. Obliczenia zostały przeprowadzone dla pola parametrów:

- prąd zgrzewania i = 8,0 / 9,0/10,0/11,0/12,0 kA,

- siła docisku elektrod $P=110 / 165 / 220 / 330 / 440$ daN (tj. $50 / 75 / 100 / 150 / 200 \%$ nominalnej siły docisku),

- czasu zgrzewania 60 (slop) + 240 ms (razem 300 ms, analiza dla czasów 0 / 50 / 100 / 150 / 200 / 250 ( $300 \mathrm{~ms}$ )

W kolumnie A zamieszczono wyniki dotyczące różnych analizowanych wartości siły docisku. Kolumna ta została podzielona na pięć części od A1 do A5 gdzie zamieszczono odpowiednio parametry i wyniki obliczeń dla:

- część A1 - siła docisku 110 daN,

- część A2 - siła docisku 165 daN,

- część A3 - siła docisku 220 daN,

- część A4 - siła docisku 330 daN,

- część A5 - siła docisku 440 daN.

W kolumnie B zamieszczono wyniki dotyczące charakteru budowy (pełne, pierścieniowe) i wielkości (średnicy) jądra zgrzeiny. Odpowiednim kolorem zaznaczono charakter przebiegu procesu i efekt finalny, w postaci jądra zgrzeiny, dla wybranych czasów zgrzewania:

- kolumna B1 - czas zgrzewania $50 \mathrm{~ms}$,

- kolumna B2 - czas zgrzewania $100 \mathrm{~ms}$,

- kolumna B3 - czas zgrzewania $150 \mathrm{~ms}$,

- kolumna B4 - czas zgrzewania $200 \mathrm{~ms}$,

- kolumna B5 - czas zgrzewania $250 \mathrm{~ms}$,

- kolumna B6 - czas zgrzewania $300 \mathrm{~ms}$,

W tablicy llb zamieszczono różne (rozróżniane) kategorie zgrzeiny końcowej:

- jądro pełne, zgrzewanie bez wyprysku, średnica jądra zgrzeiny powyżej $6 \mathrm{~mm}$ - kolor zielony,

- jądro pełne, bez wyprysku, średnica jądra zgrzeiny
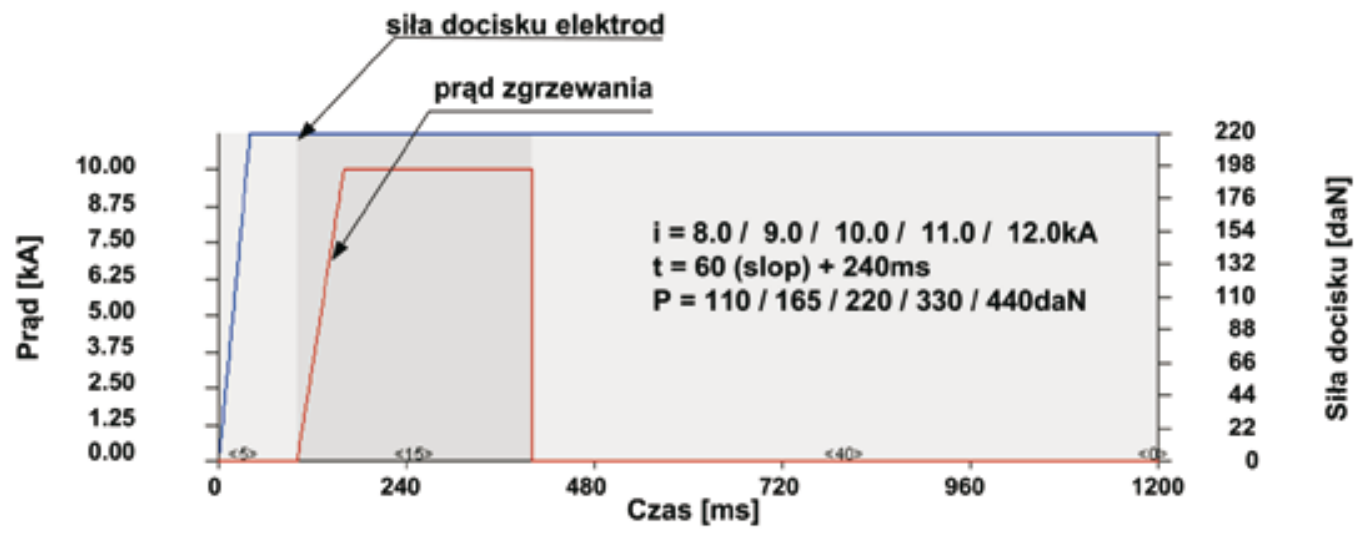

Rys. 2. Zastosowany w obliczeniach program zgrzewania garbowego z dociskiem pneumatycznym. Parametry przyjęte do obliczeń: wartości prądu zgrzewania 8, 9, 10, 11, $12 \mathrm{kA}$, czas zgrzewania $300 \mathrm{~ms}$ (60 ms slop + $240 \mathrm{~ms})$ i siła docisku (110, 165, 220, 330 i 440 daN)

Fig. 2. Projection welding programme with pneumatic pressure used in calculations. Parameters adopted for calculations: welding current values of $8,9,10,11$ and $12 \mathrm{kA}$, welding current of $300 \mathrm{~ms}(60 \mathrm{~ms}$ slop $+240 \mathrm{~ms})$ and pressure force $(110,165,220,330$ and 440 daN) 
Tablica I. Wyniki obliczeń MES i parametry zadane dla garbu niepełnego typu C (DX53 x 2, grubość 1,5 mm)

Table I. FEM calculation results and parameters pre-set for incomplete projection of type C (DX53 $\times 2$, thickness $1.5 \mathrm{~mm}$ )

Garb niepelny typ C, DX53 x 2, grubość $1.5 \mathrm{~mm}$

\begin{tabular}{|c|c|c|c|c|c|c|c|c|c|c|c|}
\hline A & B1 & B2 & B3 & 84 & B5 & B6 & C & D & E & $\mathbf{F}$ & G \\
\hline \multirow[t]{2}{*}{ A1 } & \multicolumn{6}{|c|}{ ezas zorzewania [ms] (dila - sala docisku 110 daN) } & prad zorz. & sersent & $\begin{array}{c}\text { Jadro } \\
\text { pientcieniomeipeine } \\
\end{array}$ & objetosc jadra & $\begin{array}{c}\text { srednica } \\
6 \mathrm{~mm}\end{array}$ \\
\hline & 50 & 100 & 150 & 200 & 250 & 300 & [KA] & |min| & [ns] & [mm3] & {$[\mathrm{mm}]$} \\
\hline \multirow{7}{*}{$\begin{array}{l}\text { srednica } \\
\text { jadra [mm] }\end{array}$} & $\begin{array}{c}\text { peine } \\
2.9\end{array}$ & $\begin{array}{l}\text { गuाp: } \\
+21\end{array}$ & 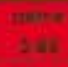 & anit & and & $\begin{array}{l}\text { netif } \\
\text { litit }\end{array}$ & 8 & 36 & 44 & 39 & \\
\hline & $\begin{array}{ll}\text { Pitr } \\
\text { is }\end{array}$ & 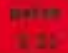 & 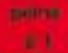 & marg & Then & $=\frac{11}{21}$ & 9 & 1) & 40 & 47 & \\
\hline & peive & netris & pains & mutre & suren & $\sum=110$ & \multirow{2}{*}{10} & \multirow[b]{2}{*}{$\mathrm{n}$} & \multirow{2}{*}{25} & \multirow{2}{*}{57} & \multirow[t]{2}{*}{139} \\
\hline & 13 & 531 & .21 & ISE & (a) & 1 & & & & & \\
\hline & rever & Per! & роия & phirs & sarse & 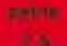 & \multirow[t]{2}{*}{11} & 0 & \multirow[t]{2}{*}{36} & \multirow[t]{2}{*}{75} & \\
\hline & 18 & ax & $x$ & te in & 125 & 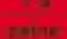 & & & & & \\
\hline & $\begin{array}{l}\text { Peive } \\
\text { tivid }\end{array}$ & De?ly & Pring & nelpes & $\begin{array}{l}\text { mare } \\
\text { tas }\end{array}$ & forle & 12 & 34 & 33 & 81 & \\
\hline
\end{tabular}

\begin{tabular}{|c|c|c|c|c|c|c|c|c|c|c|c|}
\hline \multirow{2}{*}{ A2 } & \multicolumn{6}{|c|}{ czas zgrzewania [ms] (dila - sila docisku 165daN) } & \multirow{2}{*}{$\begin{array}{l}\text { prad zorz. } \\
\text { [KA] }\end{array}$} & \multirow{2}{*}{ miteste } & \multirow{2}{*}{$\begin{array}{l}\text { Jadro } \\
\text { piertcieniowejpelne } \\
\text { [ais] }\end{array}$} & \multirow{2}{*}{$\begin{array}{c}\text { objetose jadra } \\
\text { [mm3] }\end{array}$} & \multirow[t]{2}{*}{$\begin{array}{c}\text { srednica } \\
6 \mathrm{~mm}\end{array}$} \\
\hline & 50 & 100 & 150 & 200 & 250 & 300 & & & & & \\
\hline \multirow{7}{*}{$\begin{array}{l}\text { Irednica } \\
\text { Jadra (mm) }\end{array}$} & $\begin{array}{c}\text { piersicien } \\
a\end{array}$ & $\begin{array}{c}\text { piericien } \\
0\end{array}$ & $\begin{array}{c}\text { piericien } \\
a\end{array}$ & $\begin{array}{c}\text { pierricien } \\
a\end{array}$ & $=\frac{11}{10 x}$ & sitit: & 8 & is & 215 & 13 & \\
\hline & plersicien & स्थाती & likes & $\begin{array}{l}-34 \pi \\
+23\end{array}$ & $\begin{array}{l}3(i=2 \\
t=3\end{array}$ & axto & 9 & she & 76 & 32 & \\
\hline & pierscien & lipille & 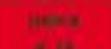 & (int & sies & inties & 10 & t & 60 & 47 & 120 \\
\hline & 0 & 44 & 14 & 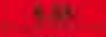 & 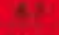 & s. & & & & & \\
\hline & $\begin{array}{c}\text { plerscien } \\
0\end{array}$ & intilo & Witist & $\begin{array}{l}\text { (1i) } \\
x=21\end{array}$ & 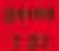 & itfis & 11 & i) & 58 & 59 & \\
\hline & D:ile & intile & Iefer: & wis & bitie & tebis & & & & & \\
\hline & 14 & With & sin & +4 & $1=4$ & 27 & 12 & 71 & 52 & 72 & \\
\hline
\end{tabular}

\begin{tabular}{|c|c|c|c|c|c|c|c|c|c|c|c|}
\hline \multirow{2}{*}{ A3 } & \multicolumn{6}{|c|}{ czas zgrzewania [ms] (dila - sila đocisku 220daN) } & \multirow{2}{*}{$\begin{array}{l}\text { prapd zgrz. } \\
\text { [kA] }\end{array}$} & \multirow{2}{*}{ maitivin } & \multirow{2}{*}{$\begin{array}{l}\text { jadro } \\
\text { pierscienibwe/polne } \\
\text { [ma] }\end{array}$} & \multirow{2}{*}{$\begin{array}{c}\text { objętost jadra } \\
\text { [mmJ] }\end{array}$} & \multirow{2}{*}{$\begin{array}{l}\text { trednica } \\
6 \mathrm{~mm}\end{array}$} \\
\hline & 60 & 100 & 160 & 200 & 250 & 300 & & & & & \\
\hline \multirow{7}{*}{$\begin{array}{l}\text { srednica } \\
\text { jadra [mm] }\end{array}$} & $\begin{array}{c}\text { pierscien } \\
0\end{array}$ & $\begin{array}{c}\text { pierscien } \\
0 \\
\end{array}$ & $\begin{array}{c}\text { pierscien } \\
0\end{array}$ & $\begin{array}{c}\text { pierscien } \\
0\end{array}$ & $\begin{array}{c}\text { piersielea } \\
0\end{array}$ & $\begin{array}{l}\text { Bewit:- } \\
\text { tit }\end{array}$ & 8 & net: & 259 & 14 & \\
\hline & $\begin{array}{c}\text { plersicien } \\
0\end{array}$ & $\begin{array}{c}\text { piericien } \\
0\end{array}$ & $\begin{array}{l}30+5 \\
345\end{array}$ & $\begin{array}{l}\text { sevax } \\
\text { 114y }\end{array}$ & 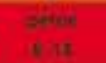 & $\begin{array}{l}\text { Buil: } \\
\text { tin }\end{array}$ & 9 & i3 & 130 & 28 & \\
\hline & plerscien & piericien & bete & stites & 3000 & boust & 10 & il & 102 & 33 & 130 \\
\hline & $\frac{0}{\text { piericien }}$ & $\frac{0}{\text { pierscien }}$ & 11 & $\begin{array}{l}15 i \\
i p\end{array}$ & Sirs & $\begin{array}{c}11 \\
\text { Bexije }\end{array}$ & & & & & \\
\hline & 0 & 0 & 27 & 401 & $\mathrm{MI}$ & 631 & 11 & (3) & 112 & 47 & \\
\hline & pericien & twis & $=+14$ & pirat & What & Hence & 12 & \pm & 67 & 60 & \\
\hline & $a$ & +12 & ser: & 11 & : 23 & 87 & 12 & 78 & & & \\
\hline
\end{tabular}

\begin{tabular}{|c|c|c|c|c|c|c|c|c|c|c|c|}
\hline \multirow{2}{*}{ A4 } & \multicolumn{6}{|c|}{ czas zgrzewania [ms] (dla - sila docisku 330daN) } & \multirow{2}{*}{$\begin{array}{l}\text { prad zorz. } \\
\text { DCA] }\end{array}$} & \multirow{2}{*}{ itind } & \multirow{2}{*}{$\begin{array}{l}\text { jadro } \\
\text { pierscienioweipeine } \\
\text { [ms] }\end{array}$} & \multirow{2}{*}{$\begin{array}{c}\text { objętost jadira } \\
\text { [mm3] }\end{array}$} & \multirow{2}{*}{$\begin{array}{l}\text { sredtnica } \\
6 \mathrm{~mm}\end{array}$} \\
\hline & 50 & 100 & 150 & 200 & 250 & 300 & & & & & \\
\hline \multirow{5}{*}{$\begin{array}{l}\text { srednica } \\
\text { jadra [mm] }\end{array}$} & $\begin{array}{c}\text { piericien } \\
0\end{array}$ & $\begin{array}{c}\text { piericien } \\
0\end{array}$ & $\begin{array}{c}\text { piersicien } \\
0\end{array}$ & $\begin{array}{c}\text { piericien } \\
0\end{array}$ & $\begin{array}{c}\text { piericien } \\
0\end{array}$ & $\begin{array}{c}\text { piersicien } \\
0\end{array}$ & 8 & OK. & pierseieniows & 1,3 & \\
\hline & $\begin{array}{c}\text { Pericien } \\
0\end{array}$ & $\begin{array}{c}\text { piericien } \\
0\end{array}$ & $\begin{array}{c}\text { pierseien } \\
0\end{array}$ & $\begin{array}{l}\text { peine } \\
5,41\end{array}$ & $\begin{array}{l}\text { peine } \\
5.41\end{array}$ & $\begin{array}{c}\text { peine } \\
5,51\end{array}$ & 9 & OK. & $m$ & 8,4 & \\
\hline & $\begin{array}{c}\text { perscimh } \\
0\end{array}$ & $\begin{array}{c}\text { pierscien } \\
0\end{array}$ & $\begin{array}{c}\text { pelne } \\
5,97\end{array}$ & $\begin{array}{l}\text { peine } \\
6,17\end{array}$ & $\begin{array}{l}\text { paine } \\
6,24\end{array}$ & $\begin{array}{l}\text { poine } \\
6,22\end{array}$ & 10 & oik. & 143 & 20 & 189 \\
\hline & $\begin{array}{c}\text { Piersciant } \\
e\end{array}$ & $\begin{array}{c}\text { piersicien } \\
0\end{array}$ & $\begin{array}{l}\text { peine } \\
5.24\end{array}$ & $\begin{array}{l}\text { pelne } \\
6,56\end{array}$ & $\begin{array}{l}\text { poine } \\
6,87\end{array}$ & $\begin{array}{l}\text { poine } \\
6,87\end{array}$ & 11 & OK. & 129 & 26 & \\
\hline & $\begin{array}{c}\text { pierscien } \\
0\end{array}$ & $\begin{array}{c}\text { pierscien } \\
0\end{array}$ & $\begin{array}{l}\text { pelne } \\
6.57\end{array}$ & $\begin{array}{l}\text { peine } \\
7.05\end{array}$ & $\begin{array}{l}\text { peine } \\
7.02\end{array}$ & $\begin{array}{l}\text { poine } \\
7,13\end{array}$ & 12 & OK. & 111 & 37 & \\
\hline
\end{tabular}

\begin{tabular}{|c|c|c|c|c|c|c|c|c|c|c|c|}
\hline \multirow{2}{*}{ A5 } & \multicolumn{6}{|c|}{ czas zgrzewania [ms] (dia - sila docisku 440daN) } & \multirow{2}{*}{$\begin{array}{l}\text { prad zgrz. } \\
\text { [RA] }\end{array}$} & \multirow{2}{*}{$y=2}$, & \multirow{2}{*}{$\begin{array}{l}\text { iqdro } \\
\text { piersicienioweipeine } \\
\text { (ms) }\end{array}$} & \multirow{2}{*}{$\begin{array}{c}\text { objetose jadra } \\
\text { [mm3] }\end{array}$} & \multirow{2}{*}{$\begin{array}{c}\text { Srednica } \\
6 \mathrm{~mm}\end{array}$} \\
\hline & 50 & 100 & 150 & 200 & 250 & 300 & & & & & \\
\hline \multirow{5}{*}{$\begin{array}{l}\text { irednica } \\
\text { jadra [mm] }\end{array}$} & $\begin{array}{c}\text { plerseien } \\
0\end{array}$ & $\begin{array}{c}\text { piericien } \\
a\end{array}$ & $\begin{array}{c}\text { pintusion } \\
a\end{array}$ & $\begin{array}{c}\text { pierselen } \\
0\end{array}$ & $\begin{array}{c}\text { Diersieien } \\
\text { o }\end{array}$ & $\begin{array}{c}\text { piericien } \\
0\end{array}$ & 8 & OK. & piertcientowe & 0,7 & \\
\hline & $\begin{array}{c}\text { Dierscien } \\
a\end{array}$ & $\begin{array}{c}\text { glersicien } \\
a\end{array}$ & $\begin{array}{c}\text { Dierseioh } \\
a\end{array}$ & $\begin{array}{c}\text { pierseien } \\
\text { o }\end{array}$ & $\begin{array}{c}\text { Piaricien } \\
0\end{array}$ & $\begin{array}{c}\text { plerscien } \\
0\end{array}$ & 9 & OK. & pierscientowe & 2.9 & \\
\hline & piertieien & $\begin{array}{c}\text { Diersicien } \\
0\end{array}$ & pierscien & pierseien & $\begin{array}{c}\text { peine } \\
5,56\end{array}$ & $\begin{array}{c}\text { peine } \\
5,56\end{array}$ & 10 & OK. & 210 & 12 & brak \\
\hline & pierdicien & $\begin{array}{c}\text { Diericien } \\
\text { a }\end{array}$ & $\begin{array}{c}\text { pierscien } \\
0\end{array}$ & $\begin{array}{c}\text { pelne } \\
5,79\end{array}$ & $\begin{array}{c}\text { pelne } \\
5,79\end{array}$ & $\begin{array}{c}\text { pelne } \\
5,79\end{array}$ & 11 & OK: & 186 & 8,3 & \\
\hline & $\begin{array}{c}\text { pierdcien } \\
\text { o }\end{array}$ & $\begin{array}{c}\text { piericien } \\
0\end{array}$ & $\begin{array}{c}\text { peine } \\
5,97\end{array}$ & peine & $\begin{array}{c}\text { peins } \\
6.6\end{array}$ & $\begin{array}{l}\text { petine } \\
6,6\end{array}$ & 12 & oK. & 136 & 27 & \\
\hline
\end{tabular}


powyżej $5 \mathrm{~mm}$ i poniżej $6 \mathrm{~mm}$ - kolor żółty,

- jądro pełne, bez wyprysku, średnica jądra zgrzeiny poniżej $4 \mathrm{~mm}$ - kolor niebieski,

- zgrzeina pierścieniowa - kolor brązowy,

- zgrzeina z zarejestrowanym w oprogramowaniu Sorpas wypryskiem ciekłego metalu - kolor czerwony.

W kolumnie $C$ zamieszczono zadany w obliczeniach MES prąd zgrzewania w zakresie $8 \div 12 \mathrm{kA}$.

Kolumna D zawiera informacje o czasie wystąpienia wyprysku, który był wyznaczany w czasie obliczeń MES w oprogramowaniu SORPAS. Oprogramowanie rozróżnia trzy poziomy intensywności wyprysku - low (niski), middle (średni) i high (wysoki). W przeprowadzonych wszystkich obliczeniach zjawisko wyprysku miało charakter o najniższym nasileniu tj. low.

W kolumnie E zamieszczono informacje o czasie przejścia jądra zgrzeiny z pierścieniowego $w$ pełny.

Kolumna $F$ zawiera dodatkowo informacje o uzy- skanej objętości roztopionego metalu tj. jądra zgrzeiny. W przypadku niewielkiej ilości roztopionego metalu (kilka $\mathrm{mm}^{3}$ ) świadczy to o braku utworzenia jądra o poprawnej (akceptowalnej) wielkości.

$Z$ uwagi na prowadzenie obliczeń dla stałego czasu zgrzewania (300 ms) i różnych parametrów zadanych, w kolumnie $\mathrm{G}$ zamieszczono czas w którym uzyskiwana jest nominalna średnica jądra $6 \mathrm{~mm}$.

Jako nadrzędne kryterium oceny przebiegu procesu zgrzewania przyjęto w kolejności:

- wyprysk ciekłego metalu z jądra zgrzeiny (kolor czerwony),

- budowę zgrzeiny jako pierścieniowej uzyskiwaną na koniec procesu (kolor brązowy),

- jądro pełne o średnicy powyżej $6 \mathrm{~mm}$ (kolor zielony),

- jądro pełne o średnicy powyżej $5 \mathrm{~mm}$ i poniżej $6 \mathrm{~mm}$ (kolor żółty),

- jądro poniżej średnicy $4 \mathrm{~mm}$ (kolor niebieski)

Tablica II. Wyniki zbiorcze obliczeń MES dla garbu niepełnego (DX53 x 2, grubość 1,5 mm, garb C)

Table II. Overall FEM calculation results for incomplete projection (DX53 × 2, thickness $1.5 \mathrm{~mm}$, projection C)

a)

Garb niepelny typ C, DX53 x 2, grubość $1.5 \mathrm{~mm}$

b)

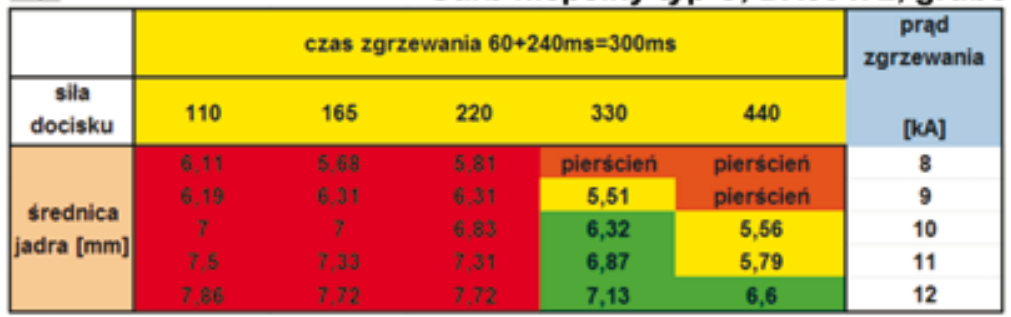

\begin{tabular}{|l|}
\hline kategorie zgrzein dla garbu niepelnego: \\
\hline - jaqdro pelne - (bez wyprysku, średnica $>6 \mathrm{~mm}$ ) \\
\hline - jądro pelne - (bez wyprysku, $6 \mathrm{~mm}>$ średnica $>5 \mathrm{~mm}$ ) \\
\hline - jaqdro pelne - (bez wyprysku, średnica $<4 \mathrm{~mm}$ ) \\
- zgrzeina pierścieniowa \\
\hline
\end{tabular}

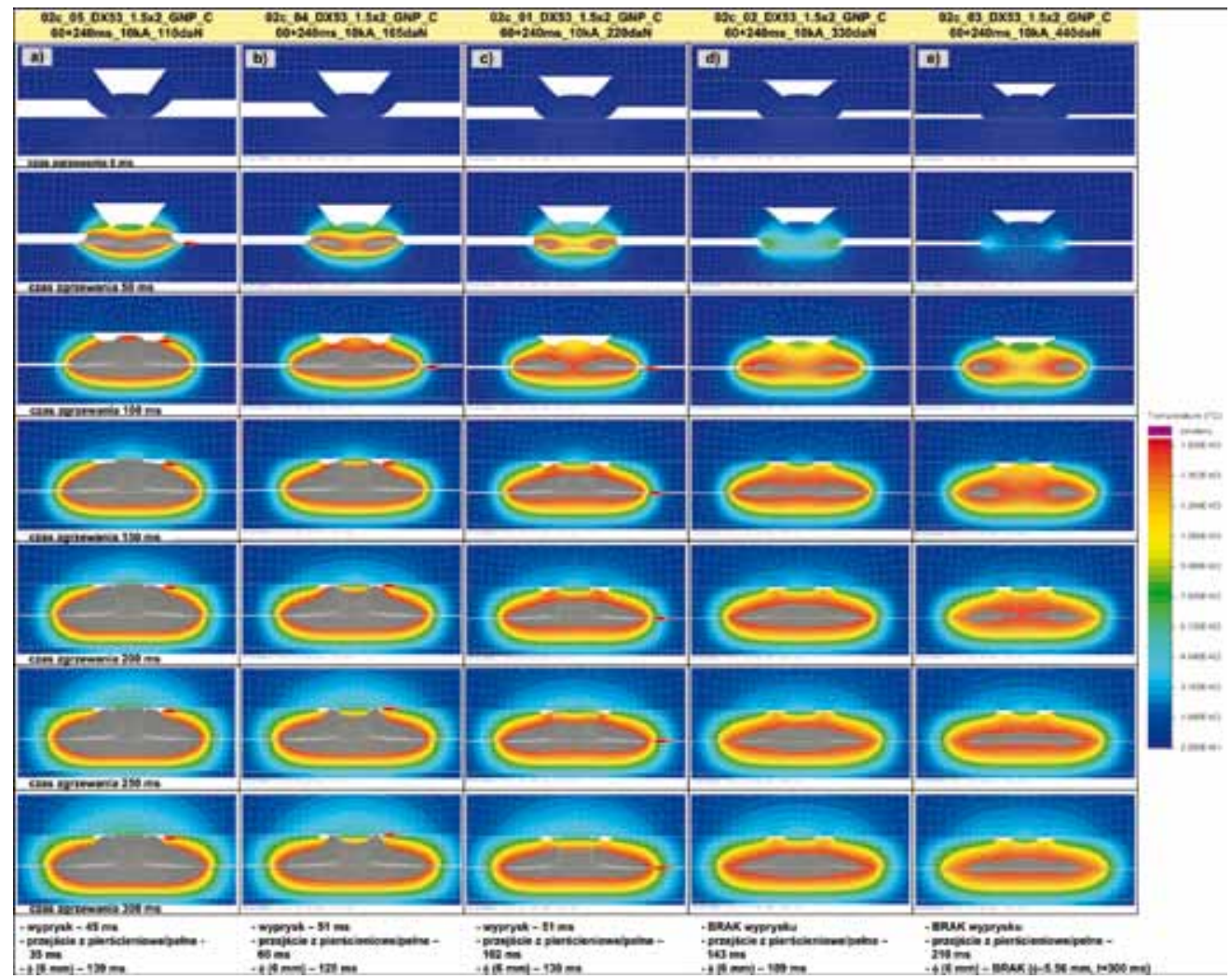

Rys. 3. Proces tworzenia złącza garbowego (rozkład temperatury) z dociskiem pneumatycznym dla wybranych czasów przepływu prądu zgrzewania (0, 50, 100, 150, 200, 250 i $300 \mathrm{~ms}$ ), prądu zgrzewania 10,0 kA, i siły docisku a) 110 daN, b) 165 daN, c) 220 daN, d) 330 daN, e) 440 daN Fig. 3. Process of projection joint formation (temperature distribution) with pneumatic pressure for selected welding current flow times ( $0,50,100$, 150, 200, 250 and $300 \mathrm{~ms}$ ), welding current $10.0 \mathrm{kA}$, and pressure force a) $110 \mathrm{daN}$, b) $165 \mathrm{daN}, \mathrm{c}) 220 \mathrm{daN}, \mathrm{d}) 330 \mathrm{daN}, \mathrm{e}) 440 \mathrm{daN}$ 
W tablicy II, w części a zamieszczono końcowe wyniki obliczeń MES dla siły docisku w zakresie 110 $\div 440$ daN, prądu zgrzewania $8 \div 12 \mathrm{kA}$ i czasu zgrzewania $300 \mathrm{~ms}$. W części b zamieszczono rozróżnialne w czasie analizy różne kategorie zgrzeiny końcowej.

Wyniki zestawione w tablicy II stanowiły dane źródłowe do prezentacji graficznej wielkości średnicy jądra zgrzeiny w zależności od prądu zgrzewania i siły docisku przedstawionych na rysunkach 4 i 5 .

$\mathrm{Na}$ rysunku 3 przedstawiono natomiast proces tworzenia złącza garbowego w postaci obrazów rozkładu temperatury dla wybranych czasów przepływu prądu zgrzewania $(0 \div 300 \mathrm{~ms})$, siły docisku $(110 \div 440 \mathrm{daN})$ i prądu zgrzewania o wartości $10 \mathrm{kA}$.

Przedstawione przykładowe (rys. 3) obrazy analizy MES tworzenia zgrzeiny garbowej (dla prądu zgrzewania $10 \mathrm{kA}$ ) uwidaczniają wpływ siły docisku na przebieg tworzenia się zgrzeiny garbowej. Pojawiające się niepożądane wypryski ciekłego metalu z jądra zgrzeiny mają miejsce przy niższych wartościach siły docisku tj. 110, 165 i 220 daN. Wyprysk nie pojawia się przy wyższych wartościach siły docisku 330 i 440 daN, jednak dla wartości siły 440 daN już na początku procesu następuje bardzo znaczne odkształcenie garbu, a w konsekwencji nie uzyskuje się wymaganej średnicy zgrzeiny (ok. $6 \mathrm{~mm}$ ) przez cały czas przepływu prądu (300 ms). Widoczne są również na obrazach MES fazy procesu zgrzewania w których następuje charakterystyczne przejście z pierścieniowego topienia materiałów łączonych w pełne jądro zgrzeiny. Wartość siły docisku przy którym nie występują wypryski ciekłego metalu i uzyskuje się założoną średnicę jadra zgrzeiny (ok. $6 \mathrm{~mm}$ ) po upływie czasu zgrzewania $190 \mathrm{~ms}$, to wartość 330 daN.

\section{Graficzna prezentacja wyników dla garbu niepełnego}

Zebrane wyniki analizy MES zamieszczone $w$ tablicy II, zostały zaprezentowane $w$ formie graficznej w postaci przestrzennych rysunków 4 i 5 . Do utworzenia wykresów (3D) wykorzystano oprogramowania Statistica www.statistica.pl [5].

Naniesienie kolorowych płaszczyzn na rysunki 4 i 5 miało na celu przejrzyste zaznaczenie obszarów parametrów zgrzewania umożliwiających:

- uzyskanie jądra zgrzeiny większego od $6 \mathrm{~mm}$ bez wystąpienia wyprysku ciekłego metalu (kolor płaszczyzny - zielony),

- uzyskanie jądra zgrzeiny w przedziale $5 \div 6 \mathrm{~mm}$ bez wystąpienia wyprysku ciekłego metalu (kolor płaszczyzny - żółty),

- wyprysk ciekłego metalu z jadra zgrzeiny (kolor płaszczyzny - czerwony),

- obszar tworzenia się zgrzeiny pierścieniowej (kolor płaszczyzny - beżowy/brązowy).

\section{Przykładowe zestawienia wyników MES dla garbu niepełnego i pełnego}

Dla porównania przeprowadzono również obliczenia MES dla garbu pełnego o tych samych wymiarach zewnętrznych i dla tego samego materiału zgrzewanego.

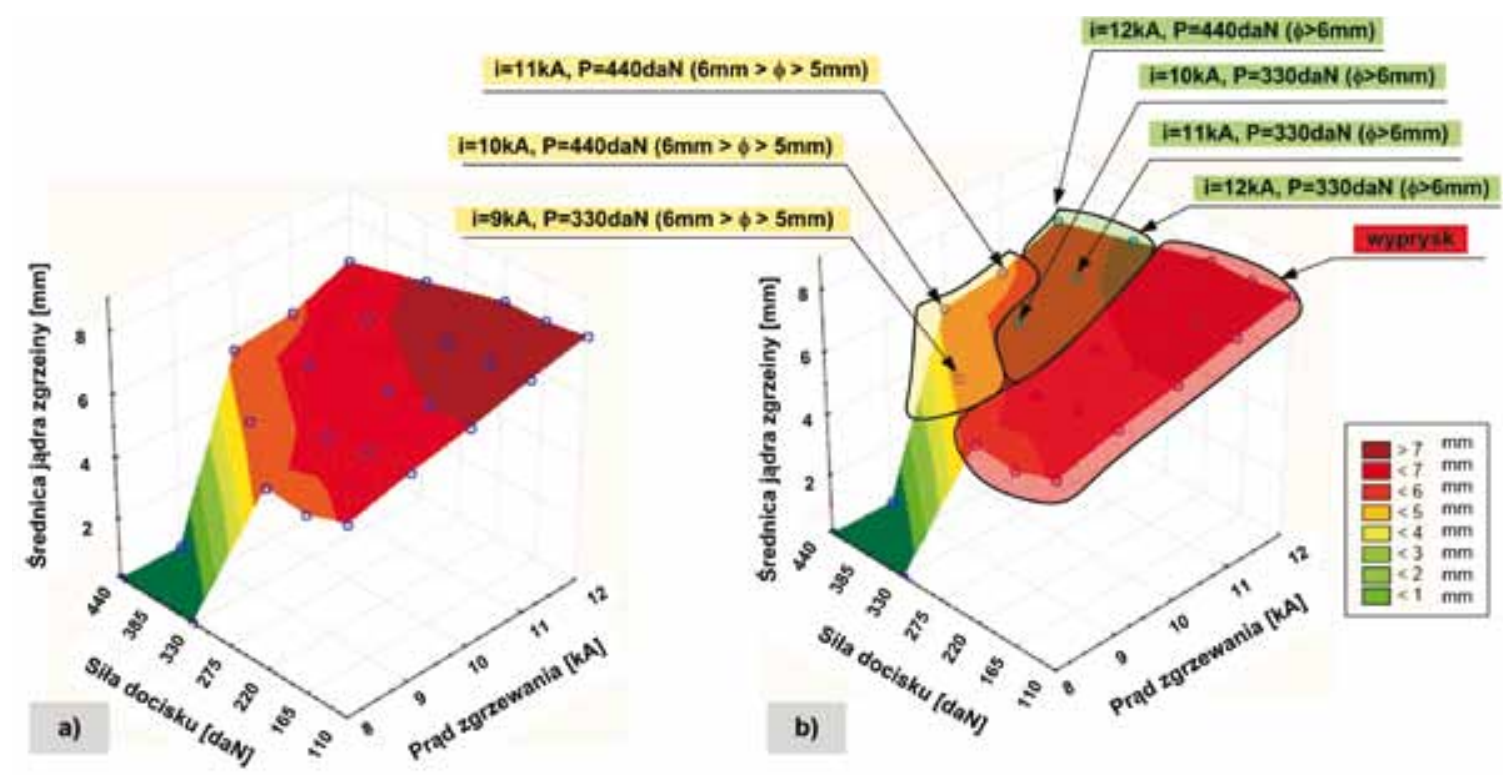

Rys. 4. Zależność średnicy jądra zgrzeiny od siły docisku (110-440 daN) i prądu zgrzewania (8-12 kA) dla garbu niepełnego (materiał zgrzewany blacha DX53 x 2, grubość $1,5 \mathrm{~mm}$ x 2, Statistica - typ wygładzania: waflowe). a) dane wyjściowe (Statistica), b) dane z zaznaczonymi obszarami obrazujące poprawną wielkości jadra $(6 \mathrm{~mm}, 5 \mathrm{~mm})$ oraz niezgodności w postaci wyprysków

Fig. 4. Dependence of weld nugget diameter on pressure force (110-440 daN) and welding current (8-12 kA) for incomplete projection (material being welded: sheet DX53 x 2, thickness $1.5 \mathrm{~mm} \times 2$, Statistica - smoothing type: wafer). a) output data (Statistica), b) data with marked areas showing correct weld nugget size $(6 \mathrm{~mm}, 5 \mathrm{~mm})$ and imperfections (spatters) 


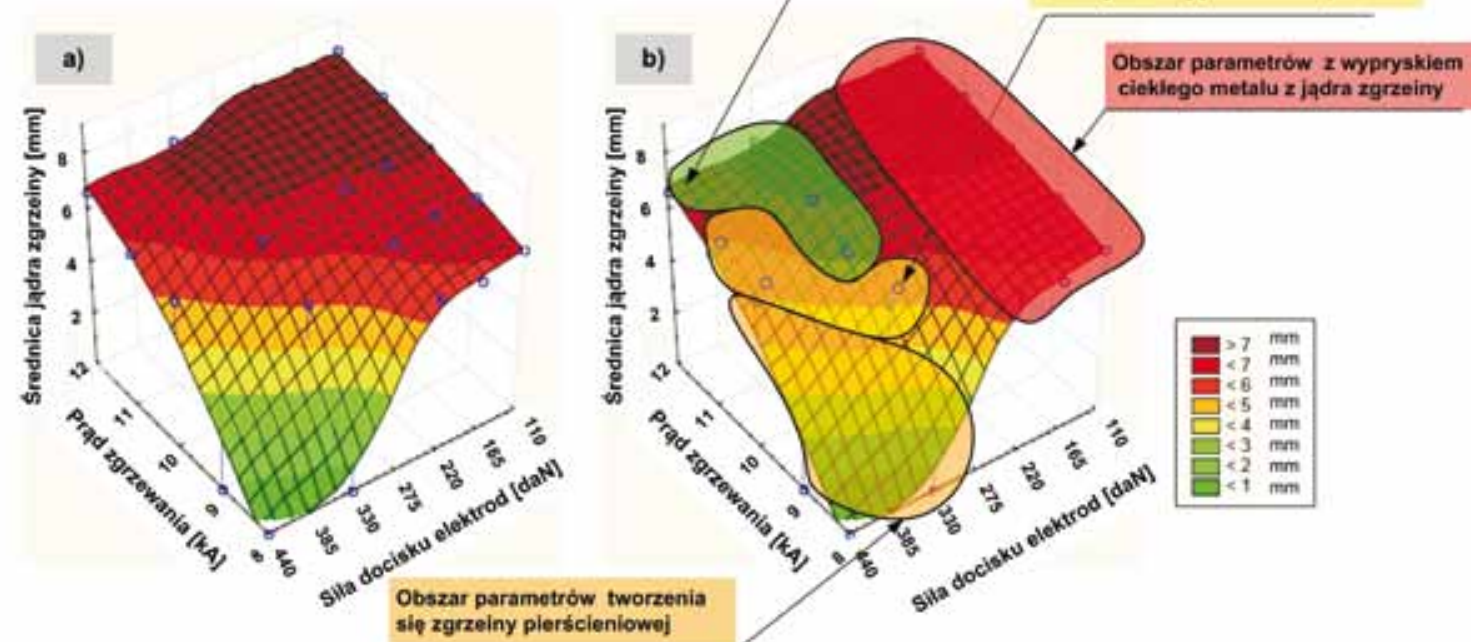

Rys. 5. Zależność średnicy jądra zgrzeiny od siły docisku (110-440 daN) i prądu zgrzewania (8-12 kA) dla garbu niepełnego (materiał zgrzewany blacha DX53 x 2, grubość $1,5 \mathrm{~mm} \times 2$, Statistica - typ wygładzania: najmniejszych kwadratów ważone odległościami): a) dane wyjściowe (Statistica), b) dane z zaznaczonymi obszarami ujmujące poprawną wielkości jadra (6 mm, $5 \mathrm{~mm}$ ) oraz niezgodności w postaci wyprysków lub jądra pierścieniowego

Fig. 5. Dependence of weld nugget diameter on pressure force (110-440 daN) and welding current (8-12 kA) for incomplete projection (material being welded: sheet DX53 $\times 2$, thickness $1.5 \mathrm{~mm} \times 2$, Statistica - smoothing type: the-least-squares distance-weighted smoothing): a) output data (Statistica), b) data with marked areas showing correct weld nugget size $(6 \mathrm{~mm}, 5 \mathrm{~mm})$ and imperfections (spatters or ring-like weld nugget)

Analiza procesu zgrzewania dla garbu pełnego, podobnie jak niepełnego, jest również zagadnieniem bardzo złożonym i wymaga szerszego wyjaśnienia. Ciekawa i zarazem istotna $z$ punktu widzenia przebiegu procesu i wyniku końcowego w postaci utworzonego jądra jest analiza rozkładu temperatury.

Przedstawione na rysunku 6 porównanie obrazów rozkładu temperatury dla garbu pełnego wskazują tak- że na niebezpieczeństwo nieuzyskania założonych wskaźników wytrzymałościowych. Przy zastosowaniu tych samych parametrów zgrzewania jak dla garbu niepełnego, możliwe jest uzyskanie zbyt małej średnicy jądra zgrzeiny, a jego usytuowanie może być nieznacznie oddalone od powierzchni stykających się blach łączonych co skutkuje brakiem połączenia.

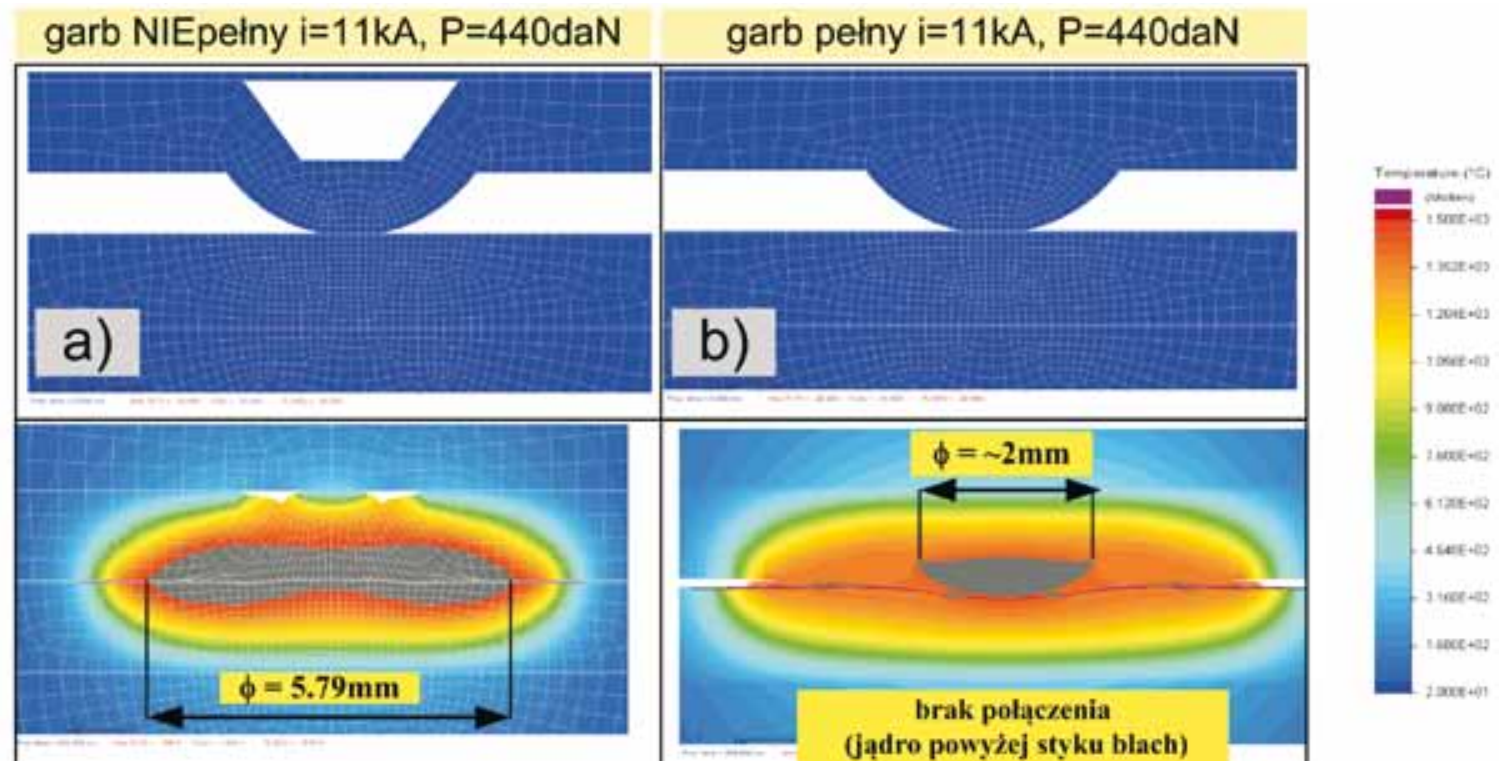

Rys. 6. Wymiary i usytuowanie jądra zgrzeiny uzyskanej przy użyciu tych samych parametrów podczas zgrzewania garbu niepełnego (a) i garbu pełnego (b)

Fig. 6. Dimensions and location of weld nugget obtained using the same parameters during welding an incomplete projection (a) and complete projection (b) 


\section{Wnioski}

W oparciu o przedstawioną analizę należy stwierdzić, że dobór poprawnych parametrów w procesie

zgrzewania garbowego garbów niepełnych, bez dodatkowego wspomagania w postaci modelowania numerycznego MES, jest trudny do jednoznacznego ustalenia. Do analizy przyjęto rozszerzony zakres parametrów znacząco przekraczający zalecany zakres parametrów nominalnych (i=10 kA, P=220 daN, $\mathrm{t}=240 \mathrm{~ms}$, uznawanych jako najkorzystniejsze warunki zgrzewania i zalecany w literaturze spawalniczej) odnoszącesię do garbu niepełnego typu C i grubości blach1,5 mm gatunku DX53.

Wyniki w postaci rozkładu temperatury obszaru zgrzewania w procesie tworzenia połączeń garbowych dla przyjętej wartości prądu 10 kA, czasów zgrzewania 0, 50, 100, 150, 200, 250 i 300 ms i sił docisku z przedziału $110 \div 440$ daN, pozwalają zaobserwować warunki sprzyjające występowaniu niepożądanemu zjawisku wyprysku metalu z jądra zgrzeiny oraz niedostatecznej średnicy jądra a także połączenia o charakterze zgrzeiny pierścieniowej

Analiza umożliwia utworzenie wykresów przestrzennych w których w sposób bardzo przejrzysty widoczne są obszary charakteryzują się:

- poprawnym zbiorem parametrów końcowych:

- klasa A, $\varnothing>6 \mathrm{~mm}$ (płaszczyzna koloru zielona),

- klasa B, $6>\varnothing>5 \mathrm{~mm}$ (płaszczyzna koloru żółtego),

- występowaniem niezgodności:

- zgrzeina pierścieniowa (płaszczyzna koloru brązowego),

- wyprysk metalu jądra zgrzeiny (płaszczyzna koloru czerwonego).

\section{Literatura}

[1] http://sorpas.com/

[2] Papkala H.: Zgrzewanie oporowe metali, wydawnictwo KaBe Krosno 2003.

[3] Papkala H.: Wytyczne doboru właściwej technologii zgrzewania punktowego, garbowego i liniowego blach w oparciu o właściwości fizyczne metali. Instytut Spawalnictwa Gliwice. 1990.

[4] Poradnik Inżyniera, Spawalnictwo tom 1, 2 WNT Warszawa 2005.

[5] www.statistica.pl

Artykuł zawiera wyniki prac badawczych finansowanych ze środków Narodowego Centrum Nauki realizowanych $w$ ramach projektu przez Instytut Spawalnictwa oraz Politechnikę Wrocławską i Politechnikę Warszawską w latach 2011-2013. s o s n o w i e c exposilesia

ExpoWELDING czołowe targi spawalnicze w środkowej Europie MUSISZ TU BYĆ!

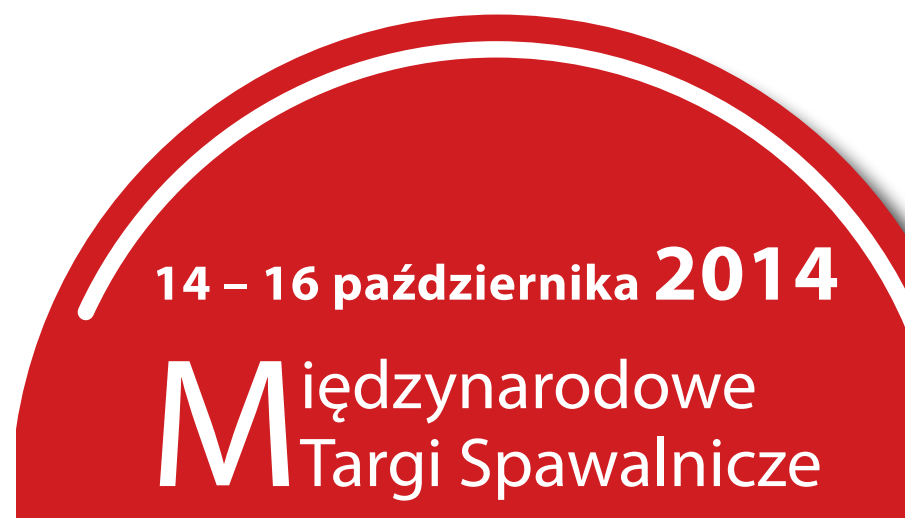

Zarezerwuj swój czas aby uczestniczyć w targach

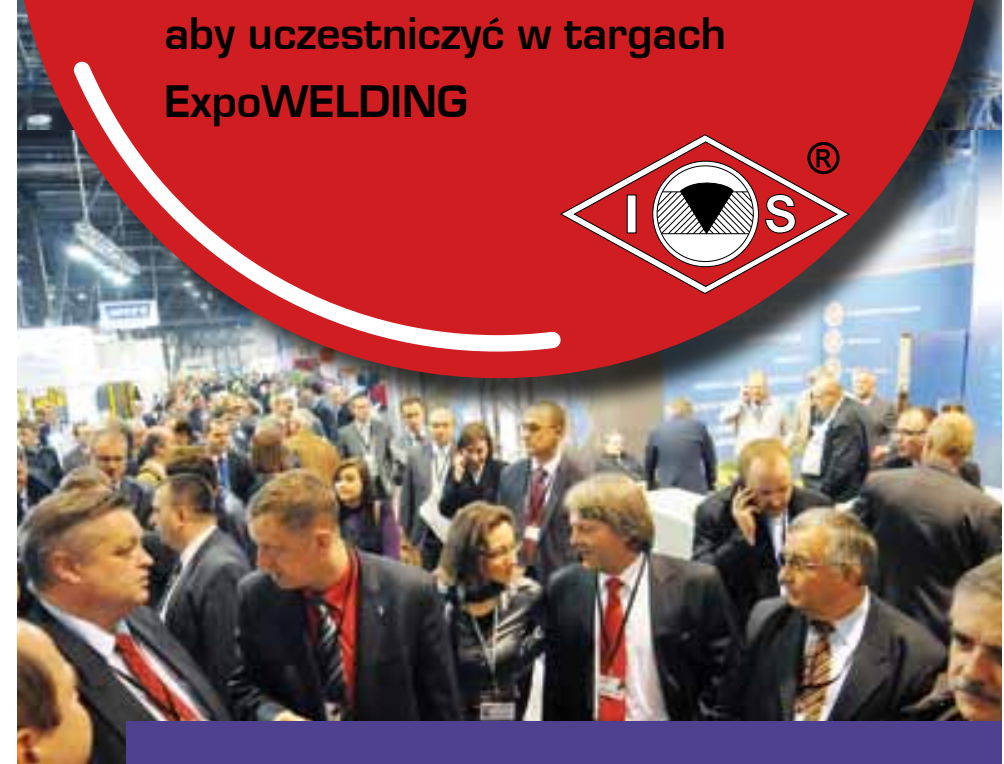

- Najważniejsze targi spawalnicze w Europie Środkowo - Wschodniej

- Międzynarodowe grono profesjonalistów

- Nowości i premiery prezentowane przez wystawców

- Prestiżowa Konferencja Instytutu Spawalnictwa

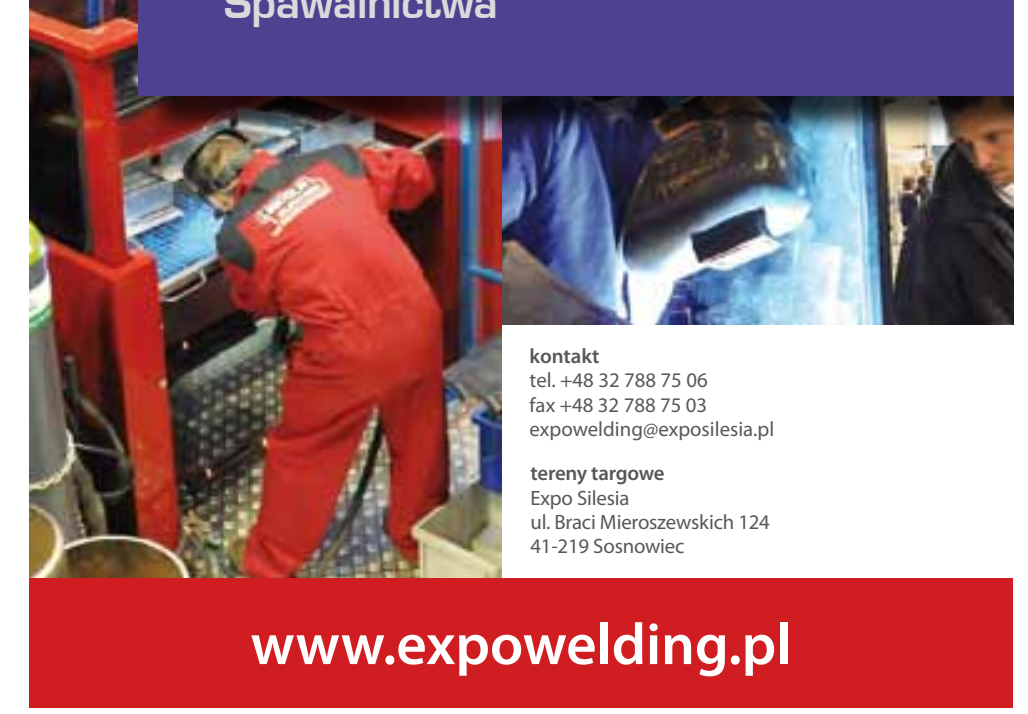

